JUN 2. A 1989 Sta. 15

\begin{tabular}{|l|l|}
\hline $\begin{array}{l}\text { 2. To: (Receiving Organization) } \\
\text { GJ Gauck, SST Engineering }\end{array}$ & $\begin{array}{l}\text { 3. From: (Originating Organization) } \\
\text { AM Ermi, COGEMA Engineering }\end{array}$ \\
\hline $\begin{array}{l}\text { 5. Proj./Prog./Dept./Div.: } \\
\text { SST Engineering }\end{array}$ & $\begin{array}{l}\text { 6. Design Authority/Design Agent/Cog. Engr.: } \\
\text { GJ Gauck }\end{array}$ \\
\hline
\end{tabular}

8. Originator Remarks:

Operational Test Report (OTR) for the DACS remote portion of the Upgrade System. This OTR reports the results of the OTP that was performed on the final system following successful Dual-Mode operation in the DACS Trailer.
11. Receiver Remarks:
11A. Design Baseline Document? $O$ Yes $O$ No
A USQ was generated to upgrade the DACS software to be $\mathrm{Y} 2 \mathrm{~K}$ compliant. The USQ number is TF-98-1059.

\begin{tabular}{|l|l|}
\hline \multicolumn{2}{|l|}{15.} \\
\hline $\begin{array}{l}\text { (A) } \\
\text { tiem } \\
\text { No. }\end{array}$ & (B) Document/Drawing No. \\
\hline 1 & HNF -3687 \\
\hline & \\
\hline & \\
\hline & \\
\hline & \\
\hline & \\
\hline & \\
\hline
\end{tabular}

16.

\begin{tabular}{|c|c|}
\hline Approval Designator (F) & \\
\hline $\begin{array}{c}\text { E, S, Q,D OR N/A } \\
\text { (See WHC-CM-3-5, } \\
\text { Sec. 12.7) }\end{array}$ & $\begin{array}{l}\text { 1. Approval } \\
\text { 2. Release } \\
\text { 3. Information }\end{array}$ \\
\hline
\end{tabular}

17.

DATA TRANSMITTED

\begin{tabular}{|l|l|}
\hline $\begin{array}{c}\text { (C) Sheet } \\
\text { No. }\end{array}$ & $\begin{array}{c}\text { (D) Rev. } \\
\text { No. }\end{array}$ \\
\hline & 0 \\
\hline & \\
\hline & \\
\hline & \\
\hline & \\
\hline
\end{tabular}

(E) Title or Description of Data Transmitted DACS Remote Interface OTR

KEY
Reason for Transmittal (G)
4. Review
5. Post-Review
6. Dist. (Receipt Acknow. Required)

4. Related EDT No:

$$
\mathrm{N} / \mathrm{A}
$$

7. Purchase Order No.:

$\mathrm{N} / \mathrm{A}$

9. Equip./Component No.:

$\mathrm{N} / \mathrm{A}$

10. System/Bldg./Facility:

12. Major Assm. Dwg. No:

$\mathrm{N} / \mathrm{A}$

13. Permit/Permit Application No.:

14. Required Response Date:

June 16,1999

\begin{tabular}{|c|c|c|c|}
\hline$(\mathrm{F})$ & $(\mathrm{G})$ & $(\mathrm{H})$ & $(\mathrm{l})$ \\
\hline $\begin{array}{c}\text { Approval } \\
\text { Desig- } \\
\text { nator }\end{array}$ & $\begin{array}{c}\text { Reason Trans- } \\
\text { mittal }\end{array}$ & $\begin{array}{c}\text { Origi- } \\
\text { nator } \\
\text { Dispo- } \\
\text { stion }\end{array}$ & $\begin{array}{c}\text { Receiv- } \\
\text { er } \\
\text { Dispo- } \\
\text { sition }\end{array}$ \\
\hline & & 1 &
\end{tabular}

\begin{tabular}{|ll}
\hline \multicolumn{3}{|c}{ Disposition $(\mathrm{H})$ \& $(\mathrm{l})$} \\
$\begin{array}{ll}\text { 1. Approved } & \text { 4. Revjewed no/comment } \\
\text { 2. Approved w/comment } & \text { 5. Reviewed w/comment } \\
\text { 3. Disapproved w/comment } & \text { 6. Receipt acknowledged }\end{array}$
\end{tabular}

SIGNATURE/DISTRIBUTION

(See Approval Designator for required signatures)

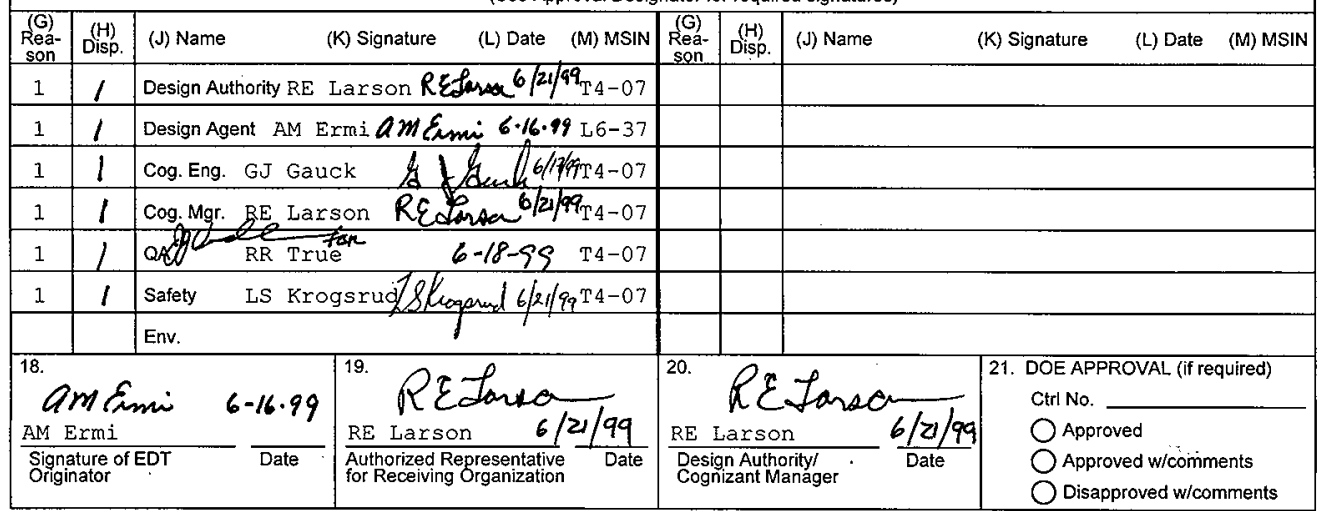




\title{
241-SY-101 Data Acquisition and Control System (DACS) Remote Operator Interface Operational Test Report
}

\author{
A. M. Exmi \\ COGEMA Engineering Corporation, 2.0. BOX 840 \\ Richland, WA 99352 \\ U.S. Department of Energy Contract DE-AC06-96RL13200
}

\author{
EDT/ECN: 140129 \\ UC: 2030 \\ Org Code: $S 4100$ \\ Charge Code: 102525 / BC20 \\ HN920201 \\ B\&R Code: EW3120072 \\ Total Pages: $\quad 35$
}

Key Words: DACS, DATA ACQUISITION AND CONTROL SYSTEM, 241SY101, MIXER PUMP, OTR, UPGRADE, Y2K

\begin{abstract}
The readiness of the upgraded 241-SY-101 Data Acquisition and Control System (DACS) to provide proper control and monitoring of the mixer pump and instrumentation in tank 241-SY-101 was evaluated by the performance of OTP-440-001. Results of the OTP are reported here.

${ }^{*}$ CyberResearch is a registered trademarks of CyberResearch, Inc. * Micron is a registered trademark of Micron System, Inc.
\end{abstract}

TRADEMARK DISCLAIMER. Reference herein to any specific commercial product, process, or service by trade name, trademark, manufacturer, or otherwise, does not necessarily constitute or imply its endorsement, recommendation, or favoring by the United States Government or any agency thereof or its contractors or subcontractors.

Printed in the United States of America. To obtain copies of this document, contact: Document Control Services, P.O. Box 950, Mailstop H6-08, Richland WA 99352, Phone (509) 372-2420; Fax (509) 376-4989.

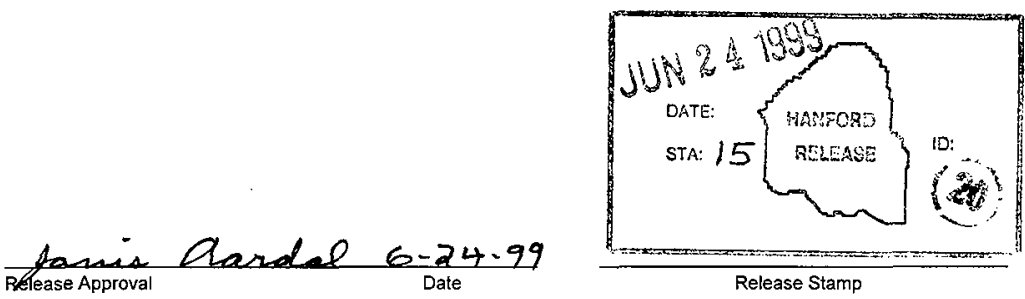




\title{
241-SY-101 DATA ACQUISITION AND CONTROL SYSTEM (DACS) REMOTE OPERATOR INTERFACE OPERATIONAL TEST REPORT
}

\section{HNF -3687 \\ Revision 0}

\author{
Prepared By: \\ A. C. Zuehlke \\ PLCs Plus, Richland, WA \\ for \\ Lockheed-Martin Hanford Company, Richland, WA
}

June 1999 


\section{TABLE OF CONTENTS}

Summary of OTP-440-001, "241-SY-101 Data Acquisition and Control System (DACS)

Remote Operator Interface Operational Test Procedure", Revision 0. .3

OTP-440-001, "241-SY-101 Data Acquisition and Control System (DACS) Remote Operator Interface Operational Test Procedure", Revision 0. 
Summary of OTP-440-001, "241-SY-101 Data Acquisition and Control System (DACS) Remote Operator Interface Operational Test Procedure", Revision 0.

Testing commenced on 6/9/1999 and was completed on 6/10/1999.

The completed procedure consists of 7 test sections, Sections 5.1 through 5.7:

$\times \quad$ Section 5.1 performed checks of the system security functions, including 4 levels of passwords.

$\times \quad$ Section 5.2 tested the station 7 display screen functions, including navigation between screens and verification of controls built-in to individual screens.

$\times \quad$ Section 5.3 performed verifications of individual trend displays available from the [TRENDS] screen at station 7.

$X \quad$ Section 5.4 performed additional [TRENDS] screens checks using Tables A and B.

$\times$ Section 5.5 performed a comparison of values displayed on screens at stations 5,6 , and 8 in the DACS trailer to values displayed on the same screens at station 7 in the DACS trailer.

$\times \quad$ Section 5.6 tested the capability to perform mixer pump runs with station 7 as the pump control station.

$\times \quad$ Section 5.7 performed tests to verify the proper functioning of Stations 11,13 , and 15, the three DACS Remote Supervisory Stations (RSSs). The ability to connect to the DACS trailer from each RSS was demonstrated, the data displayed on the screens at each RSS was verified to be accurate, and the ability to properly disconnect each RSS from the DACS trailer was demonstrated.

Nine Test Exceptions were written during testing to document typographical errors, steps out-ofsequence or missing, and actual problems encountered during testing.

$X \quad$ Test Exception \#1 documented that testing was performed at a different mixer pump rotational angle than the test originally specified.

$X \quad$ Test Exception \#2 documented that the supervisor level password no longer has sufficient security level to place tags in Auto or Manual, only Trainer and Administrative level passwords are now given permission for these actions.

$\times \quad$ Test Exception \#3 documented that all required changes to this procedure will be made as pen-and-ink changes to the original document only, and that no PCA will be issued, since this is a "one time only" use procedure.

\begin{tabular}{|c|c|c|}
\hline PROCEDURE NUMBER: & Revision Number:. & Page Number: \\
HNF-3687 & 0 & 3 of 34 \\
\hline
\end{tabular}


$\times \quad$ Test Exception \#4 documented that the software version being tested was a more recent version than stated in the procedure.

$\times \quad$ Test Exception \#5 changed a procedural error that checked for the dates that various stations were brought on-line in the DACS trailer. The procedure called for the date that the test was performed, while the actual and true displayed date was the date that each station was last started up.

$\times \quad$ Test Exception \#6 changed a procedural error that checked for the dates of recent logins at the various stations in the DACS trailer. The procedure called for the date that the test was performed, while the actual and true displayed date was the date that the latest login at each station actually occurred.

$\times \quad$ Test Exception \#7 documented a manually entered change of the run time for a specified pump run, to shorten the required test time.

$\times \quad$ Test Exceptions \#8 and \#9 documented incorrect DACS displays on the [PUMPRUN] screen at Station 8 during testing, at the end of the specified pump run. This portion of the test was reperformed satisfactorily.

All nine Test Exceptions were resolved by making pen-and-ink changes to the procedure or by retesting the affected portions of the procedure. No open Test Exceptions remain. The substitution of steps and the additions to steps were within the scope of USQ TF-98-1059.

The OTP was successfully and satisfactorily completed.

The remainder of this Operational Test Report (OTR) consists of all of the pages of the OTP, which describe the testing that was conducted and attest to the results that were obtained.

The page numbers for the OTR appear in the lower left-hand corner of the page and the page numbers of the original OTP were left for reference.

\begin{tabular}{|c|c|c|}
\hline PROCEDURE NUMBER: & Revision Number: & Page Number: \\
HNF-3687 & 0 & 4 of 34 \\
\hline
\end{tabular}


DACS REMOTE OPERATOR INTERFACE OPERATIONAL TEST REPORT

OTP-440-001, "241-SY-101 Data Acquisition and Control System (DACS) Remote Operator Interface Operational Test Procedure", Revision 0.

\begin{tabular}{|c|c|c|}
\hline PROCEDURE NUMBER: & Revision Number: & Page Number: \\
HNF-3687 & 0 & 5 of 34 \\
\hline
\end{tabular}




\section{1-SY-101 DATA ACQUISITION AND CONTROL SYSTEM (DACS) REMOTE OPERATOR INTERFACE TEST}

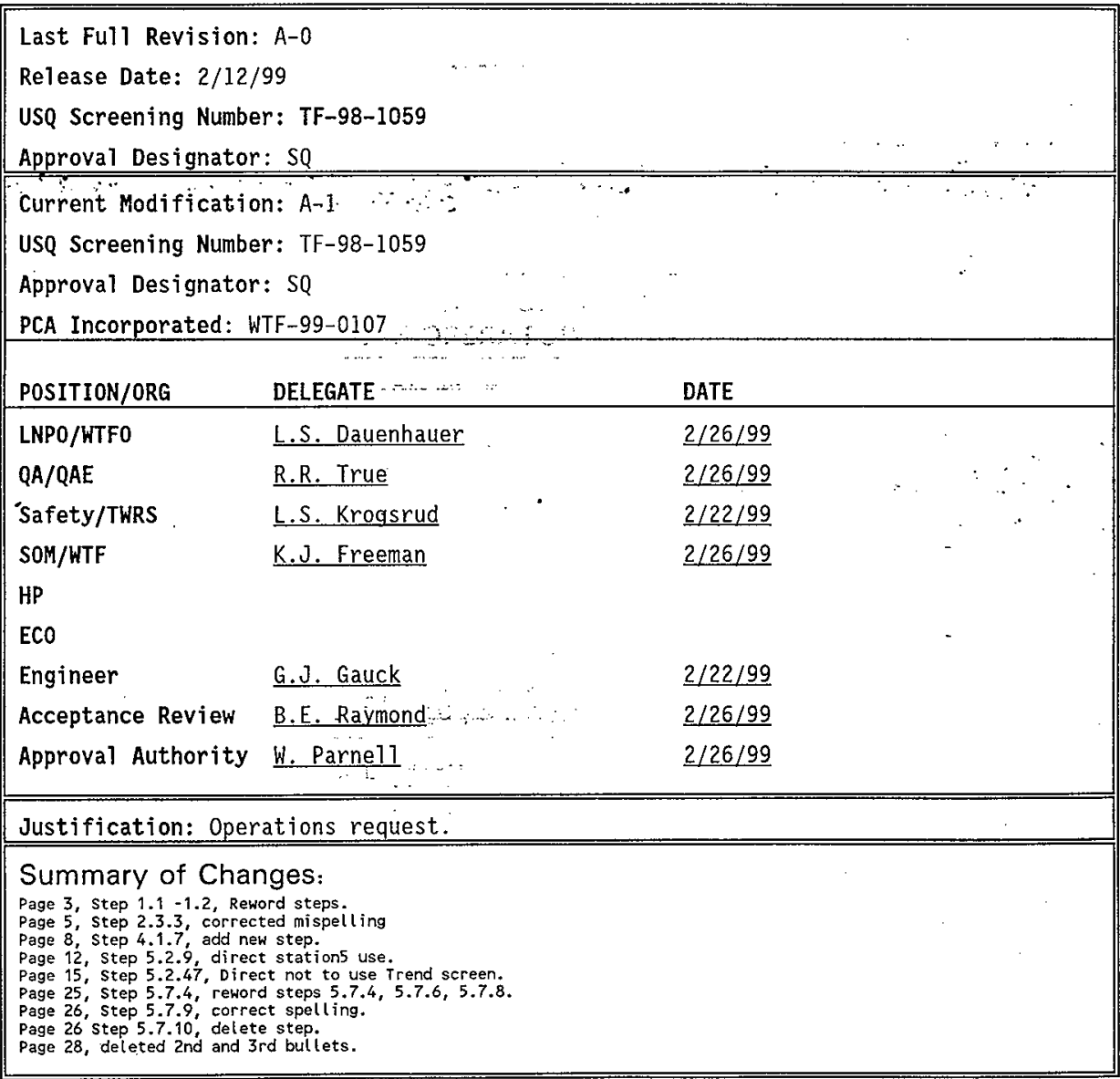




\section{TABLE OF CONTENTS}

1.0 PURPOSE AND SCOPE $\ldots \ldots \ldots \ldots \ldots$

1.1 PURPOSE $\ldots \ldots \ldots \ldots$

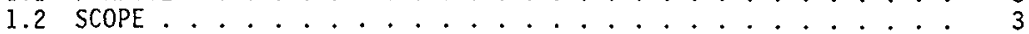

2.0 INFORMATION . . . . . . . . . . . . . . ...... 4

2.1 TERMS AND DEFINITIONS .................. 4

2.2 RESPONSIBILITIES . . . . . . . . . . . . . . . . . . 4

2.3 REFERENCES ................. . . . 5

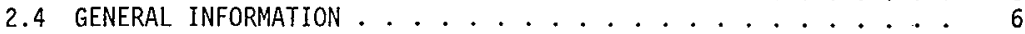

2.5 RECORDS ...................... 6

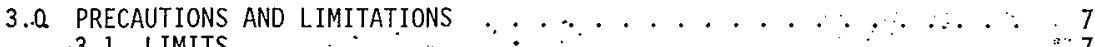
3.1 LIMITS . . . . . . . . . . . . .

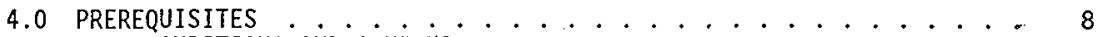

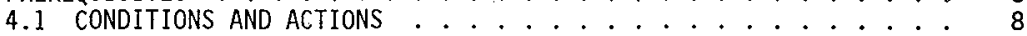

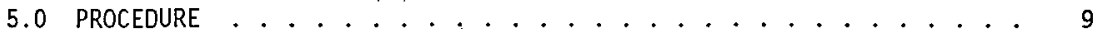

5.1 SYSTEM SECURITY CHECKS . . . . . . . . . . . . . . 9

5.2 DISPLAY SCREEN CHECKS . . . . . . . . . . . . . . . 11

5.3 TREND SCREEN CHECKS :................ 17

5.4 PERFORM TABLE A AND TASKS ............... 18

5.5 SCREEN DISPLAY VERIFICATION CHECKS ............ 21

5.6 PUMP OPERATION CHECKS ............... 23

5.7 REMOTE SUPERVISORY STATION (RSS) CHECKS $\ldots \ldots \ldots . . . . . . .25$

ATTACHMENT 1 - EXCEPTION LIST . . . . . . . . . . . 27

ATTACHMENT 2 - FINAL PROCEDURE ACCEPTANCE SHEET . . . . . . . . 28

PROCEDURE HISTORY SIGNATURE SHEET . . . . . . . . . . . . 29 


\subsection{PURPOSE AND SCOPE}

\subsection{PURPOSE}

This procedure provides instructions for readiness of the final portion of the upgraded 241-SY-101 Data Acquisition and Control System (DACS) computer system to provide proper monitoring of the mitigation mixer pump and instrumentation installed in the 241-SY101 underground storage tank, from Station 7 and the Remote Supervisory Stations (RSSs), w77 be systematieally-evaluated by the performance of this procedure.

\subsection{SCOPE}

This procedure involves the Intellution Human-Machine Interface (HMI) software program at Stations $7,11,13$, and 15 be toprovide:

- Adequate operator display screens.

- Proper alarm notification and display.

- Proper abort notification and display.

- Proper operator control interface capability.

- Proper system security, including passwords and levels of authorization for system use.

Testing will be performed in the DACS trailer, located in the 200 West Area of the Hanford site, and from the various RSS locations around the Hanford site. This procedure will be performed after successful performance of OTP-440-002, 241-SY-101 Data Acquisition and Control System (DACS) Operator Interface Upgrade Operational Test Procedure in the DACS Trailer.

During this test, the DACS trailer will be configured in the firal configuration for use of the FIX32 software and the upgraded computer system. 


\subsection{INFORMATION}

\subsection{TERMS AND DEFINITIONS}

2.1.1 In this procedure the term select means that the person performing the test should position the mouse pointer over the button, icon, or other item on the computer dispiay screen and click the left mouse button.

2.1.2 OPS . Is the name and password for operator leve? access to the DACS for testing purposes.

2.1.3 SUPER Is the name and password for supervisor level access to the DACS for testing purposes.

$2.1 .4{ }_{A}: \because$. Is the name, and there is no password for administrator/developer leveT access to the DACS for testing purposes.

\subsection{RESPONSIBILITIES}

2.2.1 DACS Cognizant Engineer: The engineer assigned direct responsibility for the performance, preparation, and adequacy of the test.

2.2.2 Test Director: The engineer assigned shift responsibility. for performance of the test. 


\subsection{REFERENCES}

2.3.I HNF-1516, Thermocouple Module Halt Fai]ure Acceptance Test Procedure For Tank 241-SY-101 DACS-1, Revision 0

2.3.2 HNF-2989, 241-SY-101 Data Acquisition and Control System (DACS) Operator Interface Upgrade Acceptance Test Procedure, Revision 0

2.3.3 OTP-440-002, 241-SY-101 Data Acquisition and Control System (DACS) Operator Interface Upgrade Operational Test Procedure, Revision 0

2.3.4 WHC-SD-WM-ATP-046, 101-SY Mitigation Testing Acceptance Test Procedure, Revision 0

2.3.5 WHC-SD-WM-ATP-058, 10i-SY Post Pump-Installation Acceptance Test Procedure, Revision 1

2.3.6 WHC-SD-WM-ATP-06I, MIT Acceptance Test Procedure, Revision 0

2.3.7 WHC-SD-WM-ATP-062, Phase B Mitigation Testing Software Acceptance Test Procedure, Revision 0

2.3.8 WHC-SD-WM-ATP-069, Acceptance Test Procedure For Tank Bottom Thermocouples On Tank 241-SY-101, Revision 2

2.3.9 WHC-SD-WM-ATP-070, 101-SY Post Phase B Acceptance Test Procedure, Revision 0-A

2.3.10 WHC-SD-WM-ATP-082, DACS Upgrade Acceptance Test Procedure, Revișion 0

2.3.11 WHC-SD-WM-ATP-098, GMS/DACS Interface Acceptance Test Procedure, Revision 0

2.3.12 WHC-SD-WM-ATP-107, MIT Upgrade Acceptance Test Procedure, Revision 1

2.3.13 WHC-SD-WM-ATP-128, Operator Coil Monitoring Acceptance Test Procedure, Revision 0 


\subsection{GENERAL INFORMATION}

The portion of the upgraded DACS computer system to be tested per this procedure consists of one CyberResearch $400 \mathrm{Mhz}$ Personal Computer (PC), (DACS Trailer Station 7), and three Micron $400 \mathrm{Mhz}$ PCS (Remote Supervisory Stations 11, 13, and 15). The connection for RSS 17 (any laptop computer with a modem and the proper software) will not be tested since this access capability will only be available to development personnel.

The portions of the system to be tested include:

- Operator display screens and screen controls.

- System alarming and alarm display functions.

$\therefore$ - System security jmplementation and password control..

\subsection{RECORDS}

At the completion of all testing, approval of all data collected and system performance shall be documented on Attachment 2, "Final Procedure Acceptance Sheet". 


\subsection{PRECAUTIONS AND LIMITATIONS}

\subsection{LIMITS}

3.1.1 Any required changes to this procedure shall be approved by the DACS Cognizant Engineer, or a designated representative, and may be made as pen-and-ink changes in all official and working copies of the procedure. An entry shall be made in the official Test Log fully describing the change or changes and the reason for the change $(s)$. A PCA, documenting the change or changes, Estexception $\# 3$ shall be initiated by the DACS Cognizant Engineer and approved per administrative requirements.

If, during testing, any indicated parameter or control.

function is not correct or appears to be malfunctioning, then the engineer conducting this test shall make a. determination as to the feasibility of continuing testing. Since actual mitigation mixer pump operation will not occur during this test, there should be no safety impact to continuing the test and completing corrective actions later. A record of all noted deficiencies will be kept on Attachment 1, "Exception List".

\subsubsection{Unexpected Alarms}

If unexpected SY Tank Farm equipment alarms or abnormal indications are received during testing; testing evolutions shall be immediately suspended and actions, as prescribed in approved SY Tank Farm Alarm Response and Emergency Procedures, shall be taken by responsible facility personnel to place the equipment/facility-in a safe, stable condition. When the reason for the unexpected condition is understood and resolved, then testing activities may be resumed after permission to do so is received from the West Area Shift Manager (WASM). 


\subsection{PREREQUISITES}

\subsection{CONDITIONS AND ACTIONS}

X4.1.1 Only properly trained and qualified Operations personnel designated by the West Area Shift Manager (WASM) and the DACS Cognizant Engineer are allowed to direct testing per this procedure, and perform equipment operating and control functions.

X 4.1.2 One engineer acting as a Test Director is required to be present during testing.

$\times$ 4.1.3 Prior to initiation of testing and at the start of each shift during tessiting, test personnel shall be briefed on the scope of testing to be conducted during the shift: The briefing shall include any equipment to be operated or controlled during the shift. Additionally, a discussion of work in the SY Tank Farm that could affect testing shall also be held between the WASM and the Test Director in charge of the test to be conducted.

4.1.4 Prior to initiation of testing, the following items shall be verified:

X.1.5 The upgraded DACS Station 7 and RSS Station 11, 13, and 15 computers are instayjed and ready for testing.

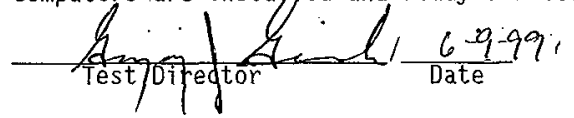

Y4.1.6 The Tatest version of all software and programming to be tested has been loaded on tg all DACS computers.

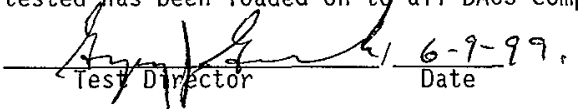

X7.1.7.

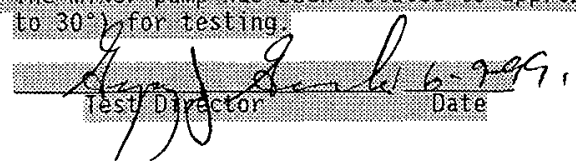

Test Exceptiven 1

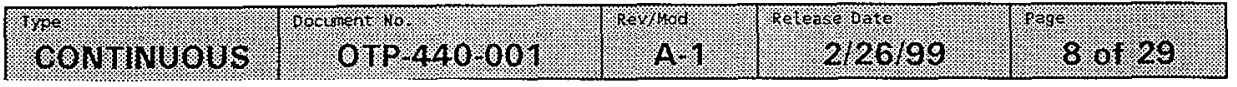




\subsection{PROCEDURE}

NOTE - Sections and steps in this procedure should be performed in the order presented to maintain the continuity of the testing sequence. The order of the performance of sections and/or steps may be varied however, at the discretion of the Test Director.

\subsection{SYSTEM SECURITY CHECKS}

$\times$ 5.1.1 IF any discrepancy is noted during testing, THEN RECORD a description of the condition in Attachment 1 .

$\times$ 5.1.1.1. For each discrepancy recorded, ENTER an identifying number in the "EXCEFTION NUMBER" Column of Attachiment 1 .

$\times$ 5.1.1.2 REPRODUCE Attachment 1 as needed, AND ATTACH the: additional pages to this procedure, to record all discrepancies noted during testing.

$\times$ 5.1.2 ENSURE that no mixer pump operations are scheduTed for at least 24 hours.

$\times$ 5.1.3 ENSURE that locaT power supply disconnect switches SY01A-WST-DS-001 and SY01A-WST-DS-002, for the mixer pump. motor and directionat drive motor, are administratively locked in. OFF.

$X 5.1 .4$ START UP the Intellution FIX32 VIEW program on the upgraded Station 5, 6, 7, and 8 DACS computers AND VERIFY that the WELCOME screen is displayed at all stations.

$X$ 5.1.5 At all stations, LOGIN as OPS.

$X$ 5.1.6 VERIFY that OPS OPERATIONS is displayed by Login: on the WELCOME screen at 211 stations.

$\times 5.1 .7 \quad$ At all stations LOGIN as SUPER.

$\times 5.1 .8$ VERIFY that SUPER SUPERVISOR is displayed by Login: on the WELCOME screen at all stations.

X 5.1.9 At all stations, LOGIN as A.

$X$ 5.1.10 VERIFY that A ADMINISTRATOR is displayed by Login: on the WELCOME screen at all stations. 


\subsection{SYSTEM SECURITY CHECKS (Cont.)}

\subsubsection{PERFORM the following:}
$X$ 5.1.11.1 LOGIN as OPS at Station 5 .
$X$ 5.1.11.2 LOGIN as OPS at Station 6 .
$\times 5.1 .11 .3$ LOGIN as SUPER at Station 7. $X^{5.1 .11 .4}$ LOGOUT at Station 8 , AND VERIFY that PUBLIC is 1isted
as the Current User.

NOTE - The alarm status of some tags shown on the TAGSTAT screen cannot. be changed. Tags. for which the alarm status cannot be changed should not be chiosen in S.tep 5.1.12.

X5.1.12 At all stations, one station at a time, ACCESS the TAGSTAT screen AND ATTEMPT to disable the alarm for any tag that has a changeable alarm status. TIR 17307 sta. $S$.

$X 5.1 .13$ VERIFY the following: $T i R 17308 \quad S t a .6$ TIRI7BO9 $5 Y_{4} .7$ TIRIZBio Sta.10.

X5.1.13.1 VERIFY NO.screen changes occur at Station 8.

X 5.1.13.2 VERIFY at Stations 5,6 , and 7 , the alarm status shows that the alarm for the selected tag is in a

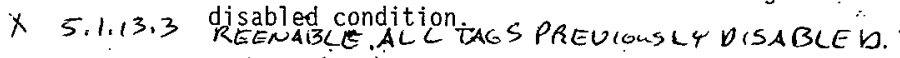

$X$ 5.1.14 At all stations, one station at a time, ATTEMPT to place any tag in Manual.

$X \quad 5.1 .15$ VERIFY the following:

$X 5.1 .16$ VERIFY NO screen changes occur at Stations $5,6,7$ and 8.

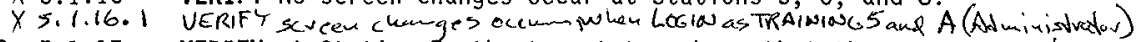

TestExcegtion $2 \times 5.1 .17$ VERIFY at Station 7 , the tag status shows that the at Stations $7 \pm 8$. selected tag is now in Manual.

X5.1.18 RETURN the Alarm and Auto/Manual status of the selected tags to normal at Stations 5, 6, and 7 .

Testing as directed by this procedure section has been completed, and discrepancies, if any, have been listed on Attachment 1 , Exception List.

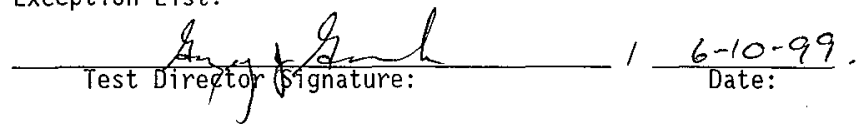

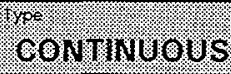

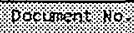

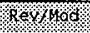
A.
R. 2126.99
$10.0 \% 29$ 


\subsection{DISPLAY SCREEN CHECKS}

X5.2.1 IF any discrepancy is noted during testing, THEN RECORD a description of the condition in Attachment 1.

$X$ 5.2.1.1 For each discrepancy recorded, ENTER an identifying number in the "EXCEPTION NUMBER" Column of Attachment 1 .

$X$ 5.2.1.2 REPRODUCE Attachment 1 as needed, and attach the additional pages to this procedure, to record all discrepancies noted during testing.

NOTE - The following steps should be performed at Station 7 .

$\therefore$ A 5:2.2 $\therefore$ With the WELCOME screen displayed, VERIFY that the date is displayed in the upper left-hand corner of the screen and that the time (in military format) is displayed in the. upper right-hand corner of the screen.

$X$ 5.2.3 VERIFY that the Version of the DACS software being tested Test Exception $\$ 4$ is and that the Version of the PLC software being tested is 3.06, as displayed below the date in the upper left-hand corner of the screen.

$X$ 5.2.4 From the WELCOME screen, SELECT any five other screens AND VERIFY that the date, time (within one minute), DACS software version number, and PLC software version number are the same as displayed on the WELCOME screen.
1) MSMAN
2) TEmPPRFL
3) ROLLONER.
4) Pumpops
5) $P \min P$. 


\subsection{DISPLAY SCREEN CHECKS (Cont.)}

X5.2.5 From the WELCOME screen, PERFORM the following for each of the listed buttons:

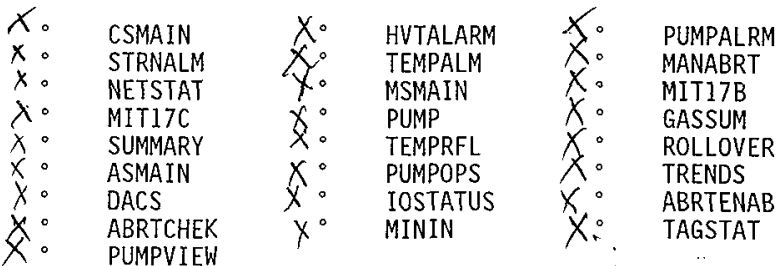

$\because X-5.2 .5 .1$ SELECT the. button.....

X5.2.5.2 VERIFY that the screen that is now displayed is the screen that should be associated with the button that was selected.

X5.2.5.3 SELECT the MAP button on the displayed screen.

$X$ 5.2.5.4 VERIFY that the MAP screen is displayed.

X5.2.5.5 SELECT the WELCOME button on the MAP screen AND

VERIFY that the WELCOME screen is displayed.

X5.2.6 SELECT the LOGIN/OUT button, select the LOGIN button on. the Login/Logout Confirmation screen, and login as OPS.

X5.2.7 PRESS the $\langle F 2\rangle$ key AND VERIFY that a Tag Status pop-up box is displayed.

\5.2.8

SELECT the ? in the Tag Status box.

X5.2.9 VERIFY that a Tag Select box is displayed Allo:

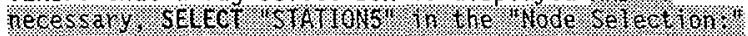

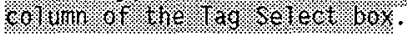

X 5.2.10 In the Tag Select box, USE the scroll bar to advance through the 1ist of the tags in the database, SELECT a tag, AND THEN SELECT the OK button.

X5.2.11 VERIFY that the Tag Select box is no longer displayed and that the tag that was selected is now displayed in the Tag Status box in the Tagname field.

X 5.2.12 SELECT OK AND VERIFY that a tag details pop-up screen is displayed providing information about the selected tag.

\begin{tabular}{|c|c|c|c|c|}
\hline 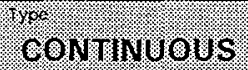 & (1) & Whor & 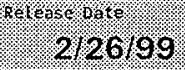 & P. \\
\hline
\end{tabular}




\subsection{DISPLAY SCREEN CHECKS (Cont.)}

X5.2.13 SELECT the CLOSE button on the tag details pop-up screen AND VERIFY that the tag details screen and the Tag Status box are no longer visible.

$X \quad 5.2 .14$ PRESS the $\langle F 4\rangle$ key AND VERIFY that the ALARMSUM screen is displayed.

$\chi \quad 5.2 .15$ SELECT the HELP button AND VERIFY that the ALARMSUM Screen Help screen is displayed.

$\times 5.2 .16$

SELECT the CLOSE button AND VERIFY that the ALARMSUM Screen Help screen is no longer displayed.

$5.2: 17^{\circ}:$ SELECT the EVENT: SUMM button AND VERIFY that a RED NOTE box is displayed with the message CLOSE ALARM/EVENT BOX WHEN NOT USING and a Select an Alarm/Event Summary File message box is disptayed.

$X$ 5.2.18 VERIFY that the Tist in the message box contains files for the last 30 days (if 30 -days of data files are available).

$\times$ 5.2.19 SELECT a file, SELECT the Enter button, AND VERIFY that the selected file is displayed in an Alarm/Event Summary File message box.

$X$ 5.2.20 SELECT the DONE button AND VERIFY that the Alarm/Event Summary File message box and the NOTE box are no longer displayed.

X 5.2.21 SELECT the PREV SCREEN button AND VERIFY that the WELCOME
screen is displayed.

$\chi 5.2 .22$ SELECT the CSMAIN button AND VERIFY that the CSMAIN screen is displayed.

$X 5.2 .23$ PRESS the $\langle$ F6 $\rangle$ key, AND VERIFY that the WELCOME screen is displayed.

5.2.24 PRESS the $\langle$ F6 $>$ key AND VERIFY that the CSMAIN screen is displayed.

$X$ 5.2.25 PRESS the <F8> key AND VERIFY that the CSMAIN Screen Help screen is displayed.

X 5.2.26 PRESS the $\langle$ F8 $>$ key AND VERIFY that the CSMAIN Screen Heip screen is no longer displayed.

$X^{5.2 .27}$ PRESS the $\langle$ Ctrl-L> keys AND VERIFY that the Login/Logout Confirmation screen is displayed. 


\title{
5.2 DISPLAY SCREEN CHECKS (Cont.)
}

\author{
$X_{5.2 .28}$ LOGIN as SUPER.
}

$X$ 5.2.29 SELECT the PRINT button AND VERIFY that a pop-up screen with the message Are You Sure That You Want To Print? is displayed.

X 5.2.30 SELECT the YES button AND VERIFY that a print of the CSMAIN screen is printed on the DACS printer and the popup screen is no longer displayed.

$X$ 5.2.31 ACCESS the WELCOME screen AND VERIFY that the P-RUN-VIS button is visible.

X.5:2.32

SELECT the P-RUN-VIS button, AND VERIFY, that on the PUMPRUN Button Visible Checklist screen, a RED checkmark is not present in the large Station 7 box near the center of the screen and that a RED checkmark is present in the box preceding Station 8 , under the Currently Enabled Stations heading.

$\Upsilon 5.2 .33$

At Station 8, VERIFY that a PUMPRUN button is visible on the following screens:

$\begin{array}{llll}\circ \quad \text { MAP } & \circ \quad \text { WELCOME GASSUM }\end{array}$

$\times 5.2 .34$

SELECT the large. Station 7 box near the center of the screen :-

$\chi^{5.2 .35}$

VERIFY that a RED checkmark becomes visible in the large Station 7 box near the center of the screen and also in the small box preceding Station 7 under the Currently Enabled Stations heading.

$X$ NOTE - Only one station may have pump control at any given time. When one station is selected as the pump control station, the other stations are automatically configured for pump operation viewing only.

X 5.2.36 VERIFY that the RED checkmark is no longer visible in the smal1 box preceding Station 8.

$X$ 5.2.37 SELECT the CLOSE button AND VERIFY that the PUMPRUN button is now visible and the PUMPVIEW button is no longer visible, on the WELCOME screen.

\begin{tabular}{|c|c|c|c|c|}
\hline & govoms & Fexmot & 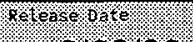 & 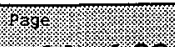 \\
\hline 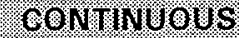 & OTP $440 \% 001$ & A. & 2126199 & 14 of 209 \\
\hline
\end{tabular}




\subsection{DISPLAY SCREEN CHECKS (Cont.)}

$X$ 5.2.38 SELECT the PUMPRUN button AND VERIFY that the PUMPRUN screen is displayed.

X 5.2.39 SELECT the HELP button AND VERIFY that the PUMPRUN Screen Help screen is displayed.

X5.2.40 SELECT the CLOSE button AND VERIFY that the PUMPRUN Screen Help screen is no longer displayed.

X5.2.41 At Station 8, VERIFY that a PUMPRUN button is no longer visible and a PUMPVIEW button is visible on the following screens:

$\therefore$ MAP $\quad \because \because \therefore$ WELCOME $\quad \because \therefore$ GASSUM

5.2.42 At Station 7, SELECT the PUMP button AND VERIFY that the PUMP screen is displayed.

$X^{5} .2 .43$ On the PUMP screen SELECT the PUMPRUN button AND VERIFY that the PUMPRUN screen is displayed.

$\times 5.2 .44$ SELECT the GASSUM button AND VERIFY that the GASSUM screen is displayed.

X5.2.45 On the GASSUM screen. SELECT the PUMPRUN button AND VERIFY: that the PUMPRUN screen is displayed.

X5.2.46 At Station 7, SELECT the MAP button AND VERIFY that the MAP screen is displayed.

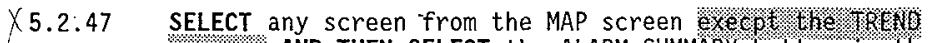
Screen: AND THEN SELECT the ALARM SUMMARY button in the Tower left-hand corner of the screen.

X5.2.48 VERIFY that the ALARM SUMMARY screen is displayed.

X5.2.49 SELECT the MAP and then NETSTAT buttons. 


\subsection{DISPLAY SCREEN CHECKS (Cont.)}

X.2.50 VERIFY the following is displayed for Stations $5,6,7$,
and 8:

X5.2.50.1 VERIFY STATUS is ONLINE (GREEN letters).

XEXcettion \#5. 5.2.50.2 VERIFY DATE is the eurfent date (GREEN letters).

$\times 5.2 .50 .3$ VERIFY TIME the approximate time of the last system startup (GREEN letters).

$\times$ 5.2.50.4 VERIFY NAME is SUPER for Station 7 , OPS for stations 5 and 6 , and PUBLIC for Station 8 (BLACK Tetters).

$\times 5.2 .50: 5$ - VERIFY GROUP' is SUPERVISOR for Station 7 , OPERATIONS for Stations 5 and 6 , and VIEW ONLY for Station 8 (BLACK letters).

$\chi$ Exception $\$ 6$ 5.2.50.6 VERIFY DATE is the date (BLACK letters).

$X$ 5.2.50.7 VERIFY TIME is the approximate time of the last user Je. Togin (BLACK letters).

X 5.2.51 At Station 7, ACCESS the WELCOME screen.

Testing as directed by this procedure section has been completed, and discrepancies, if any, have been listed on Attachment 1 , Exception List.

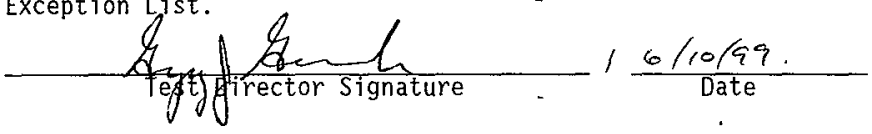

\begin{tabular}{|c|c|c|c|c|}
\hline & 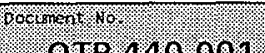 & 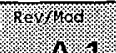 & 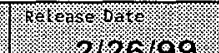 & 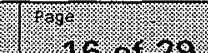 \\
\hline OONTINGOUS & OTP $440-001$ & & & 16.012 \\
\hline
\end{tabular}




\subsection{TREND SCREEN CHECKS}

X 5.3.1 IF any discrepancy is noted during testing, THEN RECORD a description of the condition in Attachment 1 .

X 5.3.1.1 For each discrepancy recorded, ENTER an identifying number in the "EXCEPTION NUMBER" Column of Attachment 1.

V5.3.1.2 RËPRoDǘ̈ Attachment 1 as needed, AND ATTACH the additional pages to this procedure, to record all discrepancies noted during testing.
$X$ 5.3.2 LOG IN to Station 7 and 8 as OPS AND VERIFY the following: is displayed on the NETSFAT screen at Station: 6 for all.. stations:
$L \quad \times 5.3 .2 .1$ VERIFY STATUS is ONLINE (GREEN letters).
$x$ Exteptions
5.3.2.2 VERIFY DATE is the date ${ }_{\lambda}$ (GREEN 1etters).
the computer stations wentor-line.
$X$ 5.3.2.3 VERIFY TIME the time on-line status was achieved (GREEN letters).
$\Varangle 5.3 .2 .4$ "VERIFY NAME is OPS (BLACK Tetters).
$\chi 5.3 .2 .5$ VERIFY GROUP is OPERATIONS (BLACK letters).

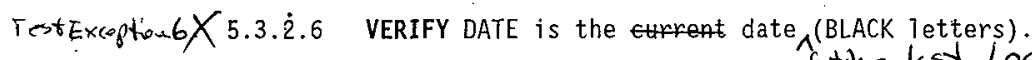

$\times$ 5.3.2.7 VERIFY TIME is the time of login (BLACK letters). $A$ the last. Log-i $N$ change.
of the $X$ 5.3.3 At Station 7, ACCESS the TRENDS screen.

$X$ 5.3.4 SELECT any PEN GROUP AND VERIFY that a pop-up screen is displayed with a listing of tagnames included in the selected pen group.

X5.3.5 USING Table A, VERIFY that the tagnames 1isted for the selected ipen group are the same as listed in Table A. Hyduagen, $\mathrm{NH}_{3}, \mathrm{~N}_{z} \mathrm{O}$ $\frac{\text { Pen-Gusups }}{\text { Hyduagen, Nitz, } \mathrm{NzO}_{2} \mathrm{O}}$ X5.3.6 REPEAT Steps 5.3.4 and 5.3.5 for two additional pen (o) irydrogen
groups, THEN GO TO Step 5.4.1. Testing as directed by this procedure section has been completed, and discrepancies, if any, have been ?isted on Attachment 1 , Exception List.

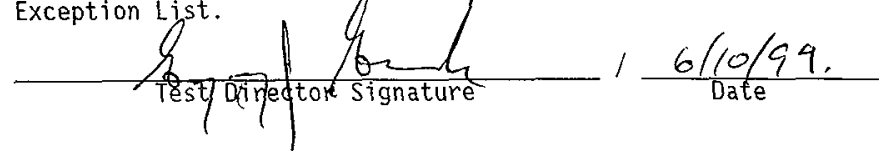




\subsection{PERFORM TABLE A AND TASKS}

TABLE A

\begin{tabular}{|c|c|}
\hline PEN GROUP & TAGS INCLUDED IN GROUP \\
\hline Tank Flow, pressure, Hydrogen & $\begin{array}{l}\text { FTE50001, FTE50002, FTE50003, PIR17Be4, } \\
\text { PIR17C01, GC2-H2, GC3-H2, NIR17BO1 }\end{array}$ \\
\hline Tank Level, Strain & LIROIA, LIRO1C, WIR12AO4 \\
\hline Pump Motor Parameters & $\begin{array}{l}\text { ZIMPE112, ZIMPE142, VR232020, YR232040, } \\
\text { VR232050, TIR12A01, TIR12A02 }\end{array}$ \\
\hline Pump pressures, Strains & $\begin{array}{l}\text { PDPBASE, PCR12A01, PITN0110, PHTN0111, } \\
\text { WİR12AOI, WIR12A02, WIR12A03, WIR12AO4 }\end{array}$ \\
\hline Strain Gauges & $\begin{array}{l}\text { WIR12A01, WIR12A02, WIR12A03, WIR12AO4, } \\
\text { WIR17CO1, WIR17CO2, WIR1BAO1, WIR1BAO2 }\end{array}$ \\
\hline Hydrogen, Vent Header & $\begin{array}{l}\text { NIR05A01, NITKSYO6, NITJSY06, NIR17BO1, } \\
\text { TT10001, MT10001 }\end{array}$ \\
\hline Hydrogen, $\mathrm{NH}_{3}, \mathrm{~N}_{2} \mathrm{O}$ & $\begin{array}{l}\mathrm{GC1}-\mathrm{H}_{2}^{2}, \mathrm{GC2}-\mathrm{H} 2, \mathrm{GC} 3-\mathrm{H} 2, \mathrm{FT}-\mathrm{N} 2 \mathrm{OC}, \mathrm{FT}-\mathrm{NH} 3 \mathrm{C}, \\
\mathrm{PHO} \text {, }\end{array}$ \\
\hline MIT17B TCS $01-08$ & $\begin{array}{l}\text { TIR17B01, TIR17B02, TIR17B03, TIR17B04, } \\
\text { TIR17B05, TIR17B06, TIR17B07, TIR17B08 }\end{array}$ \\
\hline MITIJB TCS 09-15 & $\begin{array}{l}\text { TIR17B09, TIR17B10, TIR17B11, TIR17B12, } \\
\text { TIR17B13, TIR17B14, TIR17B15 }\end{array}$ \\
\hline MITI7B TCs $16 \div 22$ & $\begin{array}{l}\text { TIR17B16, TIR17B17, TIR17B18, TIR17B19, } \\
\text { TIR17B20, TIR17B21, TIR17B22 }\end{array}$ \\
\hline MITI7C TCs $01-08$ & $\begin{array}{l}\text { TIR17C01, TIR17C02, TIR17C03, TIR17C04, } \\
\text { TIR17C05, TIR17C06, TIR17C07, TIR17C08 } \\
\end{array}$ \\
\hline MIT17C TCs $09-15$ & $\begin{array}{l}\text { TIR17C09, TIR17C10, TIRI7C11, TIR17C12, } \\
\text { TIR17C13, TIR17C14, TIR17C15 }\end{array}$ \\
\hline MIT17C TCS $16-22$ & $\begin{array}{l}\text { TIR17C16, TIR17C17, TIR17C18, TIR17C19, } \\
\text { TIR17C20, TIR17C21, TIR17C22 }\end{array}$ \\
\hline TBS TCS 01-08 & $\begin{array}{l}\text { TBSTC01, TBSTCO2, TBSTC03, TBSTC04, } \\
\text { TBSTC05, TBSTCO6, TBSTC07, TBSTC08 }\end{array}$ \\
\hline TBS TCS 09-18 & $\begin{array}{l}\text { TBSTC09, TBSTC11, TBSTC12, TBSTC13, } \\
\text { TBSTC15, TBSTC16, TBSTC17, TBSTC18 }\end{array}$ \\
\hline TBS TCS $19-26$ & $\begin{array}{l}\text { TBSTC19, TBSTC20, TBSTC21, TBSTC22, } \\
\text { TBSTC23, TBSTC25, TBSTC26 }\end{array}$ \\
\hline Weather Station & WST1, WSH1, WSP1, WSWSPD, WSWDIR \\
\hline
\end{tabular}

\begin{tabular}{|c|c|c|c|c|}
\hline & 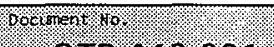 & Res/mod & 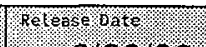 & \\
\hline CONTINUOUS & 0019440.00 & A. 1 & $241<0700$ & 18.01 .2 \\
\hline
\end{tabular}


TABLE B

\begin{tabular}{|c|c|c|c|c|c|c|c|}
\hline PEN GROUP & $1 \mathrm{hr}$ & $4 \mathrm{hr}$ & $12 \mathrm{hr}$ & $24 \mathrm{hr}$ & $72 \mathrm{hr}$ & 7 day & $\begin{array}{l}30 \\
\text { day }\end{array}$ \\
\hline Tank Flow, pressüre, & & & & & & & \\
\hline Tank Level, Strain & & & & & & & \\
\hline Pump Motor Parameters & \& & & & & & & \\
\hline Pump Pressures, 5tuny-s & & & & 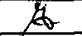 & & & \\
\hline Strain Gauges & & & & & & & \\
\hline Hydrogen, Vent Header & & & 2 & & & & \\
\hline Hydrogen, $\mathrm{NH}_{3}, \mathrm{~N}_{2} \mathrm{O}$ & & & & & & & 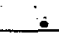 \\
\hline MIT17B TCS $01-08$ & $\therefore$ & & & $\because$ & & & 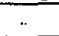 \\
\hline MIT 17B TCS $09-15$ & & .. & & & & & \\
\hline MIT178 TCS $16-22$ & & & & & & & \\
\hline MIT17C TCS $01-08$ & & $\cdots$ & & & & & \\
\hline MIT17C TCS 09-15 & & & & & & & \\
\hline MIT17C TCS 16-22 & & $\cdots$ & & & & & \\
\hline TBS TCS $01-08$ & & & & & & & \\
\hline TBS TCS 09-18: & & $\cdots$ & & & & & \\
\hline TBS TCS $19-26$ & & & & & & & \\
\hline Weather Station & & & & & & & \\
\hline
\end{tabular}




\subsection{PERFORM TABLE A AND B TASKS (Cont.)}

5.4.I USING Tables $A$ and $B$, PERFORM the following:

\5.4.1.1 SELECT a PEN GROUP.

5.4.1.2 SELECT an available historical trend for the desired pen group AND VERIFY that a Historical Display screen is visible.

X.4.1.3 VERIFY that the tagnames listed for the trends are the same as the tagnames 1 isted for the desired pen group in Table A.

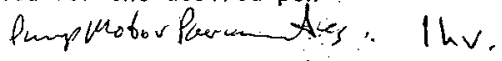

- X5.4.1.4 VERIFY that the selected trend displays the required. amount of data ("12hour's worth; 7-day's worth, etc.)

Y5.4.1.5. SELECT the File pul]-down menu AND THEN SELECT Exit to close the Historical Display screen.

5.4.1.6 IF the trend checks for a particular pen group were satisfactory, THEN INITIAL only the associated blocks in Table B.

X 5.4.1.7 REPEAT Steps 5.4.1.1 through 5.4.1.6 unti1 three pen groups and an available trend have been verified, THEN GO TO Section 5.5.

Testing as directed by this procedure section has been completed, and discrepancies, if any, have been listed on Attachment $q$, Exceptyon List.

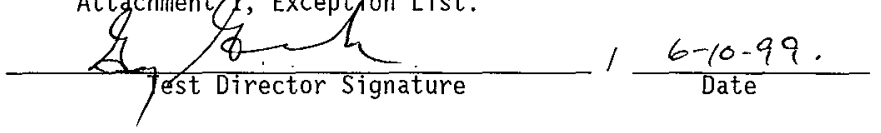

$$
\begin{aligned}
& \text { Hydrogou, Vautthader } 12 \mathrm{hu} \\
& \text { Pupp. Pressures, Strains } 24 \mathrm{hr} \text {. }
\end{aligned}
$$




\subsection{SCREEN DISPLAY VERIFICATION CHECKS}

X5.5.1 IF any discrepancy is noted during testing, THEN RECORD a description of the condition in Attachment 1 .

X5.5.1.1 For each discrepancy recorded, ENTER an identifying number in the "EXCEPTION NUMBER" Column of Attachment 1 .

$X^{5.5 .1 .2}$ REPRODUCE Attachment 1 as needed, AND ATTACH the additional pages to this procedure, to record all discrepancies noted during testing.

X5.5.1.3 At Stations 5, 6, and 8, ACCESS the following screens:

$\therefore$ HVTALARM • "PUMPALRM $\quad$ STRNALM

$Y^{5.5 .1 .4}$ At Station 7, ACCESS the following screens, one at a time, AND COMPARE the displayed values with the displayed values on the same screens at the other stations:

- HVTALARM ${ }^{\circ}$ PUMPALRM ${ }^{\circ}$ STRNALM

$X^{5.5 .1 .5}$ VERIFY that the displayed values are identical from one computer station to another.

5.5.1.6 At Stations 5, 6, and 8, ACCESS the following screens:

- TEMPALM MANABRT $\circ$ MITI7B

X5.5.1.7 At Station 7, ACCESS the following screens, one at a time, AND COMPARE the displayed values with the displayed values on the same screens at the other stations:

- TEMPALM MANABRT $\circ$ MITI7B

$X$ 5.5.1.8 VERIFY that the displayed values are identical from one computer station to another.

$X$ 5.5.1.9 At Stations 5, 6, and 8, ACCESS the following screens:

MIT17C PUMP $\circ$ GASSUM

X 5.5.1.10 At Station 7, ACCESS the following screens, one at a time, AND COMPARE the displayed values with the displayed values on the same screens at the other stations:

- MIT17C $\circ$ PUMP $\quad \circ$ GASSUM 


\subsection{SCREEN DISPLAY VERIFICÁTION CHECKS (Cont.)}

$X$ 5.5.1.11 VERIFY that the displayed values are identical from one computer station to another. $y^{5.5 .1 .12}$ At Stations 5, 6, and 8, ACCESS the following
screens:

- SUMMARY TEMPRFL $\circ$ ROLLOVER

$X$ 5.5.1.13 At Station 7, ACCESS the following screens, one at a time, AND COMPARE the displayed values with the displayed values on the same screens at the other stations:

$\therefore \quad$ SUMMARY :. $\because \quad$ TEMPRFL ROLLOVER.

X5.5.1.14 VERIFY that the displayed values are identical from one computer station to another.

5.5.1.15 At Stations 5, 6, and 8, ACCESS the following screens:

- PUMPOPS DACS $\circ$ MININ

$\times$ 5.5.1.16 At Station 7, ACCESS the following screens, one at a time, AND COMPARE the displayed values with the displayed values on the same screens at the other. stations:

- PUMPOPS DACS MININ

$\chi$ 5.5.1.17 VERIFY that the displayed values are identical from one computer station to another.

X 5.5.1.18 At Stations 5 and 6, ACCESS the following screens: - TBSTC TAGSTAT

Y5.5.1.19 At Station 7, ACCESS the following screens, one at a time, AND COMPARE the displayed values with the displayed values on the same screens at the other stations:

- TBSTC $\quad$ TAGSTAT

5.5.1.20 VERIFY that the displayed values are identical from one computer station to another.

Testing as directed by this procedure section has been completed, and discrepancies, if any, have been listed on Attachment 1, Exceptign List.

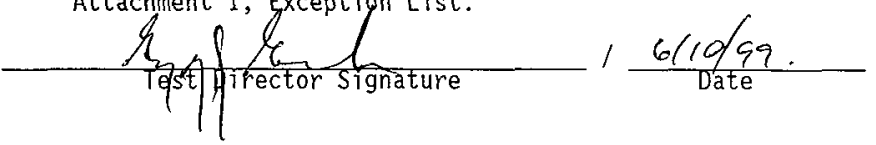




\subsection{PUMP OPERATION CHECKS}

X 5.6.1 IF any discrepancy is noted during testing, THEN RECORD a description of the condition in Attachment 1 .

5.6.1.1 For each discrepancy recorded, ENTER an identifying number in the "EXCEPTION NUMBER" Column of Attächment 1 .

X5.6.1.2 REPRODUCE Attachment $I$ as needed, AND ATTACH the additional pages to this procedure, to record all discrepancies noted during testing.

X5.6.2 IF necessary to allow testing per this procedure section, THEN DISABLE the abort coils associated with any instruments that are sènding erratic signals using the "ABRTENAB" "screen.

X5.6.3 RESET the E-Stop pushbiuttons AND VERIFY that both pushbuttons are illuminated.

$X$ 5.6.4 POSITION the E-Stop alarm silence switch to NORMAL.

X 5.6.5 ENSURE that power supply local disconnect switches SY01A-WST-DS-001 and SY01A-WST-DS-002 are sti11 administratively locked in OFF.

X 5.6.6 REQUEST the WASM to close power supply circuit breakers . SY272-EDS-BKR-123 and SY272-EDS-BKR-120.

$X$ 5.6.7 At Station " 5 , ACCESS the PUMP screen.

$X$ 5.6.8 At Station 6, ACCESS the PUMPALRM screen.

X 5.6.9 At Station 8, ACCESS the PUMPVIEW screen.

$\chi$ 5.6.10 At Station 7, ACCESS the WELCOME screen and login as SUPER.

$X$ 5.6.11 ACCESS the P-RUN-VIS screen, ENSURE that Station 7 is selected as the pump control station, AND SELECT the CLOSE button. 


\subsection{PUMP OPERATION CHECKS (Cont.)}

$$
\begin{aligned}
& \begin{array}{l}
\text { 5.6.12 At Station 7, ACCESS the PUMPRUN screen AND PERFORM the } \\
\text { following: }
\end{array} \\
& \begin{array}{l}
\text { 5.6.12.1 IF the STOP TEST button at Station } 7 \text { is GREEN, then } \\
\text { SELECT the STOP TEST button. }
\end{array} \\
& X \text { Sestereptunt } 5.6 .12 .2 .1 \text { Chasary, SELECT the Test: field AND ENTER } 1.34 \text {. } 34 \text {. } \\
& X 5.6 .12 .3 \text { SELECT the SET VALUES button. } \\
& X_{5.6 .12 .4} \text { SELECT the ENABLE TEST button. } \\
& \therefore \quad \therefore \text { X.6.12.5 SELECT the START TEST button, and, when the VSD is. } \\
& \text { running it setpoint speed VERIFY that the displayed } \\
& \text { values for pump motor Speed and Amps are consistent } \\
& \text { with the Speed and Amps values displayed on the PUMP } \\
& \text { DRIVE VSD touch pane] in the DACS Trajler. } \\
& 5,6 \text {, and } 8 \text { are consistent with the parameters } \\
& \text { displayed at Station } 7 .
\end{aligned}
$$

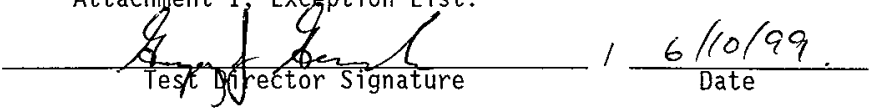




\subsection{REMOTE SUPERVISORY STATION (RSS) CHECKS}

* 5.7.1 IF any discrepancy is noted during testing, THEN RECORD a description of the condition in Attachment 1 .

X 5.7.1.1 For each discrepancy recorded, ENTER an identifying number in the "EXCEPTION NUMBER" Column of Attachment 1 .

$X$ 5.7.1.2 REPRODUCE Attachment 1 as needed, AND ATTACH the additional pages to this procedure, to record all discrepancies noted during testing.

NOTE - RSS Station 11 is located in the West Area Shift Manager's Office.

- RSS Station 13 is located in the 306E DACS Development Laboratory.

- RSS Station 15 is located in the 2750E Training Office.

- Personnel will be required to be stationed in the DACS Trailer and at the remote locations for testing per this test section.

$X \times \times 5.7 .2 \quad$ From a selected remote location, START UP the RSS computer AND DOUBLE CLICK the "RSS $X$ STARTUP" icon.

$X \times X 5.7 .3$ VERIFY that a "POP-UP" "DAIL-UP NETWORKING: screen is displayed.

$x \times \times 5.7 .4$

ON the "POP-UP" screen VERIFY that the "PHONEBOOK ENTRY TO

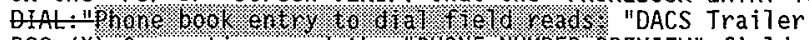
RSS $(X)$ Connection: and the "PHONE NOMBER PREVIEW" field reads the correct telephone number for the station being tested, as shown in table $c$.

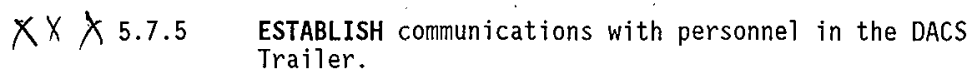

$X \times \times 5.7 .6 \quad$ SELECT the "DIAL" button AND VERIFY that the connection to the DACS Trailer is made automatically.

$X \times \times 5.7 .7 \quad$ REQUEST DACS Trailer personnel to VERIFY that the proper modem for the remote station being tested is utilized.

$X \times \times 5.7 .8$

As the phone connection to the DACS trailer is being made, VERIFY that a "DACS RSS STARTUPSTarume" message box is displayed. 


\subsection{REMOTE SUPERVISORY STATION (RSS) CHECKS (Cont.)}

$X X X 5.7 .9$. WHEN the phone connection is established, SELECT the

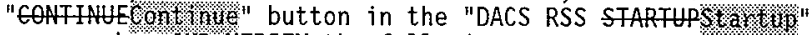
message box AND VERIFY the following:

$X X X$ 5.7.9.1 The "DACS RSS SFARTUPSI.

longer displayed.

$X \times X 5.7 .9 .2$ The FIX32 software is started up and, after a time delay, the [WELCOME] screen is displayed.

\section{7 .10 QUICKLY ACCESS several sereens ANB-VERIFY that the} displayed values for DACS parameters are ind te by "0.

- symbots.

$\therefore \quad \times \times \times 5.7 .11$

AFTER the remote station has begun updaing, ACCESS any five screens and, while in communication with personnel in the DACS Trailer, VERIFY that the values displayed for various DACS parameters are correct. RSS-11 HUTALARM RSS-1S PumpALAn $X \times X 5.7 .12$ LOGIN at the remote station as OPS. m1517 B. $X \times \times 5.7 .13$ At the remote station, ACCESS any HELP screen. MININ. $\times \times \times 5.7 .14$ SELECT the MODEM button, AND THEN SELECT the Hang Up button on the pop-up screen.

$X \times X$ 5.7.15 VERIFY that the remote station has been automatically disconnected.

$X \times X \quad 5.7 .16$ INITIAL the TEST SATISFACTORY (INITIALS) column of Table TAGSTAT Punp. ROClover DACS. $C$, if the remote station was tested satisfactorily.

$Y X X \quad 5.7 .17$ REPEAT Steps 5.7 .2 through 5.7 .16 unti1 al1 remote stations have been tested.

\section{TABLE C}

\begin{tabular}{|c|c|c|}
\hline REMOTE STATION TESTED & PHONE NUMBER DIALED & $\begin{array}{l}\text { TEST SATISFACTORY } \\
\text { (Inftials) }\end{array}$ \\
\hline RSS .11 & $372-1773$ & 4 \\
\hline RSS 13 & $373-4733$ & $A$ \\
\hline RSS 15 & $373-4163$ & $A$ \\
\hline
\end{tabular}

Testing as directed by this procedure section has been completed, and discrepancies, if any, have been 1 isted on Attachment 1, Exception List.

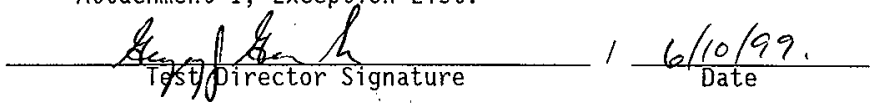

\section{TEMPALM Summiny. MiTize MININ}




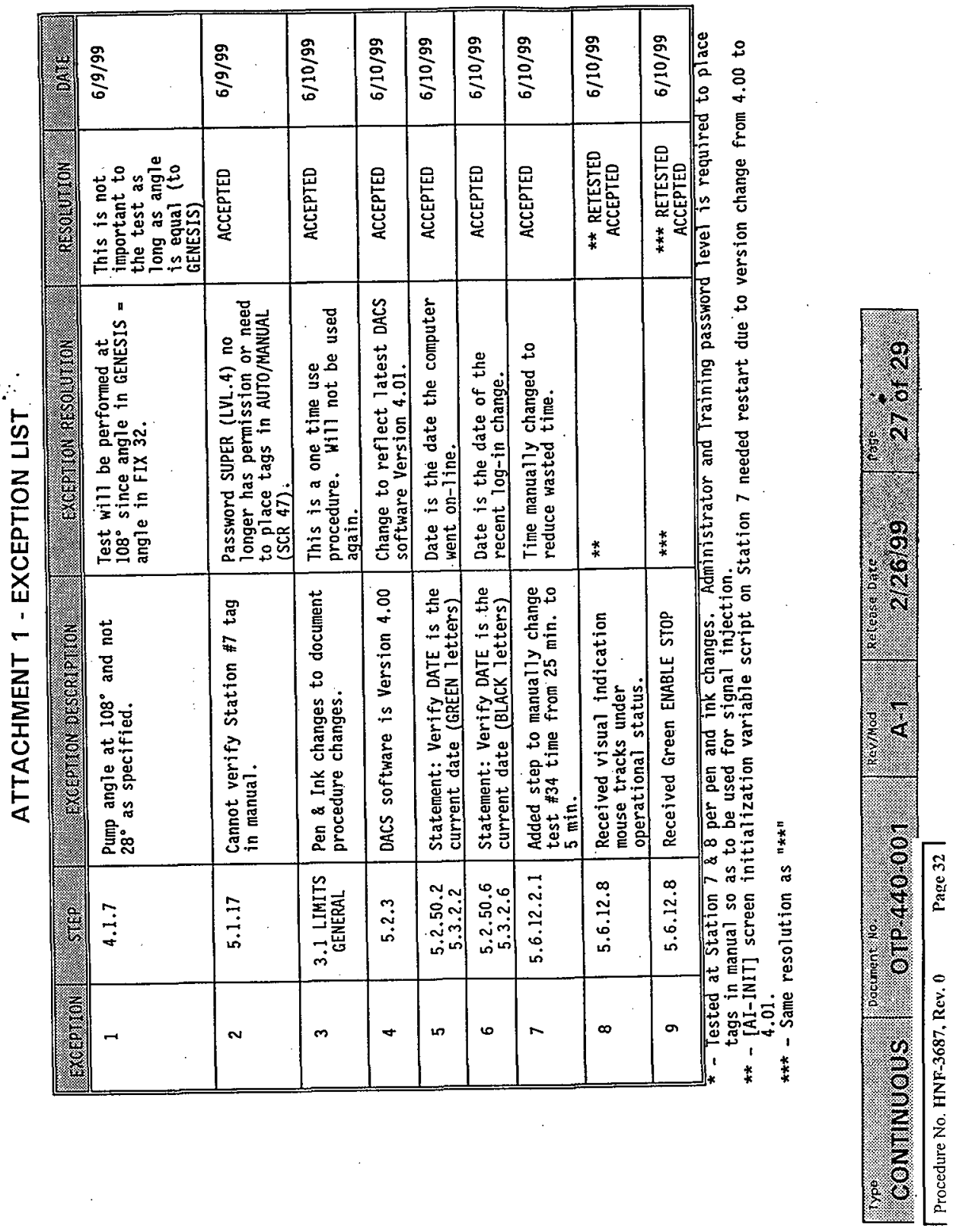




\section{ATTACHMENT 2 - FINAL PROCEDURE ACCEPTANCE SHEET}

Completion of this procedure has demonstrated that:

- Operator display and control screens at Stations 7, 11, 13 and 15 are adequate for operation, control, and monitoring of the DACS.

- Alarm notifieation and display are proper for operation, control, and menitoring of the DACS.

- Abort notification and display are proper-for operation, ent, and montoring of the DACS.

- . The DACS operator control interface capabilities have beęn tested to be adequate and satisfactory.

- Control of pump motor and directional drive motor VSDs by Station 7 is satisfactory.

- System security, including passwords and levels of authorization for system use, is satisfactory and adequate.

A record of all noted deficiencies was kept on Attachment 1, Exception List, and all recorded exceptions have been resolved and . the resolutions approved.

APPROVED BY:
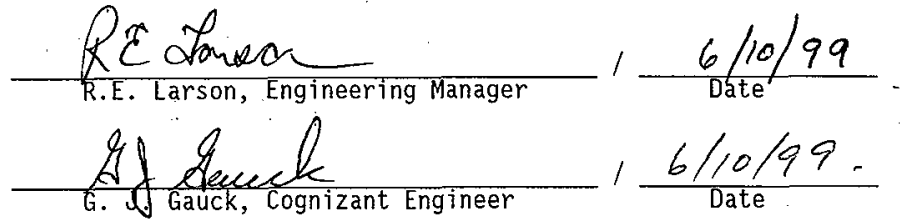

\begin{tabular}{|c|c|c|c|c|}
\hline \% & \%ormert for & 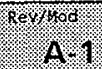 & refersegrof & . 28 of 29 \\
\hline
\end{tabular}


PROCEDURE HISTORY SIGNATURE SHEET

Last Full Revision: A-0

Release Date: 2/12/99

USQ Screening Number: TF-98-1059

Approval Designator: SQ

Current Modification: $A-0$

USQ Screening Number: TF-98-1059

Approval Designator: SQ

PCA Incorporated:

\begin{tabular}{lll} 
POSITION/ORG & DELEGATE & DATE \\
\hline LNPO/WTFO & L.S. Dauenhauer & $\underline{1 / 26 / 99}$ \\
QA/QAE & R.R. True & $\underline{1 / 28 / 99}$ \\
Safety/TWRS & $\underline{\text { L.S. Krogsrud }}$ & $\underline{1 / 28 / 99}$ \\
SOM/TW0 & $\underline{\text { O. Ravencraft }}$ & $\underline{2 / 11 / 99}$ \\
HP & $\underline{\text { M. Kornish }}$ & $\underline{2 / 12 / 99}$ \\
ECO & $\underline{\text { P.C. Miller }}$ & $\underline{2 / 11 / 99}$ \\
Engineer & $\underline{\text { G.J. Gauck }}$ & $\underline{1 / 26 / 99}$ \\
Acceptance Review & B.E. Raymond & $\underline{2 / 12 / 99}$ \\
Approval Authority & R.P. Tucker & $\underline{2 / 12 / 99}$
\end{tabular}

Justification: Y2K Compliance

Summary of Changes:

New Procedure

\begin{tabular}{|c|c|c|c|c|}
\hline 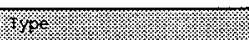 & 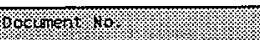 & 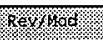 & 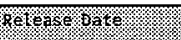 & phos \\
\hline COIMTHOOUS & OTP 440.001 & A. 1 & $2 / 26199$ & 29 or 29 \\
\hline
\end{tabular}




\section{DISTRIBUTION SHEET}

To

Distribution

Project Title/Work Order

241-SY-101 DACS Remote Operator Interface Operational Test Report 2
From

A.M. Ermi / COGEMA Engineering

M. H. Brown

A. M. Ermi (2)

G. J. Gauck

L. S. Krogsrud

D. C. Larsen

R. E. Larson

D. D. Tate

R. R. True

R. P. Tucker

Name

Central Files

DOE/RL Reading Room

$\begin{array}{llll}\text { Page } 1 \text { of } 1 \\ \text { Date June } & 16,1999\end{array}$

EDT No. 140129

ECN No. N/A

\begin{tabular}{c|c|c|c|}
\hline Text \\
$\begin{array}{c}\text { With All } \\
\text { Attach. }\end{array}$ & Text Only & $\begin{array}{c}\text { Attach./ } \\
\text { Appendix } \\
\text { Only }\end{array}$ & $\begin{array}{c}\text { EDT/ECN } \\
\text { Only }\end{array}$ \\
\hline
\end{tabular}

